\title{
COMPONENTS OF QUALITY OF PRODUCTS FOR SPECIAL MEDICAL PURPOSES
}

\section{Motuzka Iuliia}

Kyiv National University of Trade and Economics, Kyiv, Ukraine

\section{СКЛАДОВІ ЯКОСТІ ПРОДУКТІВ ДЛЯ СПЕЦІАЛЬНИХ МЕДИЧНИХ ЦІЛЕЙ}

\section{Мотузка Юлія}

Received 22.6. 2017

Products for special medical purposes are indispensable in the diet of the sick, wounded, and there are of the main factors of successful treatment and rehabilitation. This group of products has several advantages: high nutritional and biological value, physiological, easy delivery of nutrients in the human body, low level of complications and moderate cost. So, it is necessary to use of high-quality raw materials for their production, which must meet the requirements of this product group and the needs of consumers. The basic requirements for raw materials for the manufacture of products for special medical purposes are their safety, availability, confirmed clinical efficacy, high degree of purification, dispersion and solubility in water. The cost of raw materials in the production of this type of product is the main factor determining its cost and necessitates the development of the raw material base. It has been established that in the world practice of production of products for special medical purposes used to mainly vegetable and animal proteins (concentrates, isolates, hydrolyzates, peptides, and amino acids), omega-3, omega-6, omega- 9 fatty acids of plant origin, glucose, fructose, herbal extracts and powders. In order to increase the biological value of food products, food fibers, vitamins and minerals are added. Necessary and urgent are the searching of domestic raw materials, which would meet the requirements for products of this group. It will stimulate the development of the production of domestic products for special medical purposes, taking into account the specific stages of treatment and restoration of the body of person, while ensuring the optimal ratio of "price-quality".

Keywords: product for special medical purposes; raw material; protein; glucose; herbal extract; production

\section{Вступ}

Упродовж останніх років все більш затребуваними стають продукти для спеціальних медичних цілей, зокрема ентеральне харчування. Дана група продуктів має ряд переваг: високу харчову і біологічну цінність, фізіологічність, простоту доставки в організм людини поживних речовин, низький рівень ускладнень і помірну вартість. Продукти є незамінними у харчуванні хворих, поранених, постраждалих, військовослужбовців та вважаються одним із основних чинників успішного лікування та реабілітації. Це обумовлює необхідність пошуку

*Corresponding author: Iuliia Motuzka, Kyiv National University of Trade and Economics, Kyiv, Ukraine, $\triangle$ unmot@ukr.net 
та використання високоякісної сировини для їх виробництва, що повинна відповідати вимогам до цієї групи продуктів та потребам споживачів.

Основними вимогами, що ставляться перед сировиною, що використовується для виробництва продуктів для спеціальних медичних цілей, $\epsilon$ їх безпечність, доступність, підтверджена клінічна ефективність споживання, високий ступінь очищення, дисперсності та розчинності у воді (Akbaylar, 2012).

Також необхідно зазначити, що вартість сировини при виробництві цього виду продукції $€$ основним фактором, що визначаєії собівартість і обумовлює необхідність розвитку сировинної бази. Значний внесок у створення основ розробки продуктів для спеціальних медичних цілей зробили вчені А. В. Бєляєв, А.Л. Костюченко, В.М. Луфт, І. Є. Хорошилов, Н. Akbaylar, R. Bankhead, K. Barendgret, I. Mayers, A.W. Wilkinson та ін.

Метою роботи $є$ аналіз сировинної бази продуктів для спеціальних медичних цілей як складової їх якості та вирішення проблеми імпортозаміщення.

\section{Матеріали та методи}

В основу методологічної бази дослідження покладено методи наукового пізнання, системного підходу та узагальнення, наукові праці вітчизняних і зарубіжних вчених.

\section{Результати та їх обговорення}

У світовій практиці виробництва продуктів для спеціальних медичних цілей в якості основної сировини переважно використовуються: білки рослинного і тваринного походження (концентрати, ізоляти, гідролізати, пептиди, окремі амінокислоти), омега-3, омега-6, омега-9 жирні кислоти, глюкоза, фруктоза, цукрозамінники, рослинні екстракти й порошки. Для підвищення біологічної цінності до складу продуктів вносяться харчові волокна, вітаміни та мінеральні речовини (Bilsborough, 2006).

Основною сировиною, що використовується при виробництві продуктів для нутрітивної підтримки організму людини, $\epsilon$ вуглеводи. Серед них найбільш широкого використовується глюкоза. Оскільки глюкоза може розщеплюватися з виділенням енергії за відсутності кисню (гліколіз), вона засвоюється органами та тканинами для яких мітохондріальне дихання частково або повністю $\epsilon$ недоступним. До таких належать тканини в місцях уражень, коли ліпіди не можуть бути джерелом енергії через порушення кровообігу. Таким чином глюкоза $є є$ єиним енергетичним субстратом, що забезпечує живлення клітин і тканини для їхнього відновлення. Крім того, цей вуглевод підсилює окисно-відновні процеси, поліпшує антитоксичну функцію печінки, стимулює скорочувальну здатність міокарду та запобігає надлишковим втратам води організмом. Фруктоза засвоюється організмом після перетворення у глюкозу, через що $\epsilon$ відтермінованим джерелом енергії. Крім того, фруктоза не поглинається інсулін-залежними тканинами, стабілізує рівень цукру в крові, що обумовлює можливість її використання у продуктах для людей, які страждають на цукровий діабет. Дослідженнями ряду вчених доведено, що при застосуванні фруктози у продуктах для харчування пацієнтів у критичних станах спостерігається підвищення здатності клітин імунної системи до виділення субстратів, що пригнічують дію інфекційних агентів.

Обов'язковою умовою, що ставиться перед білковою складової продуктів, $\epsilon$ вміст усіх незамінних амінокислот. 3 метою забезпечення білкових потреб використовуються білкові концентрати (як тваринного, так і рослинного походження), ізоляти, пептиди, амінокислоти та їх суміші (Беляев, 2009). Головною метою їх використання $\epsilon$ забезпечення швидкого відновлення білкових втрат під дією глюконеогенезу та створення сприятливих умов для метаболічних процесів енергетичного та пластичного обміну організму. Необхідно зауважити, що головними критеріями вибору сировини для забезпечення білкової складової продуктів 
$\epsilon$ її біологічна цінність, висока розчинність, здатність стабілізувати дисперсні системи. Зважаючи на це, при виробництві продуктів для нутрітивної підтримки хворих доцільним $\epsilon$ застосування концентратів білків молочної сироватки, ізолятів соєвого білка (Kohler, 2012). Окремої уваги при характеристиці сировини, що використовується при виробництві продуктів для нутрітивної підтримки, заслуговують амінокислоти. Цінність їх використання обумовлена спрощеним процесом засвоєння та можливістю збалансувати амінокислотний склад відповідно до специфіки потреб організму. Однак, невирішеним на сьогодні залишається питання забезпечення сировиною вітчизняного виробництва та налагодження технології отримання гідролізатів білків, які краще засвоюються організмом.

Використання у складі продуктів для нутрітивної підтримки омега-3 та омега-6 поліненасичених жирних кислот зумовлено необхідністю оптимізації ліпідного обміну. У сучасній практиці виробництва продуктів для спеціальних медичних цілей у основному використовуються омега-3 і омега-6 незамінні жирні кислоти рослинного походження, що обумовлено їх більш високими органолептичними властивостями порівняно з аналогічними тваринного походження (Хорошилов, 2009). Разом з тим, дані компоненти на ринку України лише імпортного виробництва, що значно впливає на ціну готового продукту.

Широко використовуються при виробництві харчових продуктів для спеціальних медичних цілей натуральні харчові волокна (Kohler, 2014), що обумовлено їх пребіотичними властивостями та здатністю сприятливо впливати на шлунково-кишковий тракт завдяки абсорбції жовчних кислот, холестерину, покращувати моторику шлунку.

Важливим фактором, що обумовлює біологічну цінність харчових продуктів, є їхня вітамінномінеральна цінність. Для задоволення метаболічних потреб цих споживачів у мікронутрієнтах у продукти спрямовано вносяться окремі штучно синтезовані вітаміни, вітамінно-мінеральні та мінеральні премікси, мінеральні солі високого ступеня очищення [Хорошилов, 2009]. Значна увага у цьому процесі приділяється мікронутрієнтам, що характеризуються антиоксидантними властивостями. Зокрема, найбільш часто при виробництві продуктів для нутрітивної підтримки людей із соматичними захворюваннями та травмами використовуються вітаміни ретинол, аскорбінова кислота, кальциферол, токоферол, філохінон, тіамін, рибофлавін, ніацин, пантотенова кислота, піридоксин, ціанкобаламін; мінеральні солі, що призначені для забезпечення потреб у натрії, калії, кальції, магнії, ферумі, купрумі, цинку, мангані, хлорі, фосфорі, йоді.

Необхідно відмітити ще однугрупу сировини для виробництва продуктів-екстракти та порошки з рослинної сировини. Найбільш широко використовуються екстракти шипшини, ромашки, шавлії, м'яти. Подібне збагачення продуктів пояснюється їх властивостями - протизапальними, загоювальними, тонізуючими, підвищеною антиоксидантною здатністю. Окрім цього у сучасній практиці виробництва спеціальних продуктів застосовується екстракт рослини Tribulus Terreris, що містить переважно стероїдні сапоніни фуростанолового типу, серед яких переважає протодіосцин, який метаболізується в організмі людини до дегідроепіандростерона. Науково доведено, що ця речовина значно сприяє прискоренню м'язового росту, активізації білкового обміну, підвищенню рівня проникності клітинних мембранй імунітету; покращеннюметаболізму холестерину.

\section{Висновки}

Отже, сировинні компоненти є основним фактором, що обумовлює безпечність та якість продуктів для спеціальних медичних цілей і забезпечення потреб споживачів. Однак, слід зазначити, що більшість інгредієнтів $\epsilon$ імпортного походження, що унеможливлює створення дієвої альтернативи продукції іноземного виробництва. Беручи до уваги те, що розвиток виробництва вітчизняних продуктів для спеціальних медичних цілей $\epsilon$ важливою соціальною проблемою, до її розв'язання важливим $\epsilon$ привернення уваги представників державних 
органів влади, медичних закладів, наукових установ, громадських організацій, бізнес-структур. Необхідним і нагальним $\epsilon$ пошук вітчизняної сировини,яка б відповідала вимогам до продуктів даної групи. Для цього доцільним $є$ залучення потенціалу профільних установ та організацій для отримання необхідних сировинних компонентів, забезпечення науково-дослідної, практичних складових тощо. Це сприятиме стимулюванню налагодження виробництва вітчизняних продуктів для спеціальних медичних цілей з урахуванням специфіки етапів лікування та відновлення організму, при забезпеченні оптимального співвідношення "ціна-якість".

\section{Література}

Akbaylar, H. 2012. Basic principles of enteral feeding. Turk Gastroenterology, vol. 13, no. 4, p. 186-191. DOI: $10.3118 / 43$.

AKE Recommendation: Enteral and Parenteral Support in Adults. 2000. Germany, 92 p.

Bilsborough, S. 2006 A review of issues of dietary protein intake in human. Int J. Sport Nutr Exerc Metab, vol 16, no. 2, p. 129-152. DOI: 10.1278/43

Enteral formula selection: a review of selected product categories. 2011. Available at: http://www. oley.org/documents/Enteral_Formula_Selection.pdf

Food and Nutrition Communication. 2006. Available at: http://www.nestle.com/asset-library/ Documents/Library/ Documents/Nutrition_Health_Wellness/Food-and-Nutrition-Apr2006.pdf

Kohler, M. 2014. Clinical nutrition. Product Segments. Available at:Way of access http://www.fresenius. de/documents/04_CMD_2012_Clinical_Nutrition.pdf (accessed: 5. 1. 2014).

Беляев, О. В. 2009. Парентеральное и энтеральное питание в интенсивной терапии. К.: КИМ. 344 с. ISBN 873-3-440-67554-1.

Клінічний досвід. харчування хірургічних хворих. 2010. Available at: http://www.dovidnyk.org/ articles/24/49.html

Протокол нутритивной поддержки критических состояний. 2014. Available at: http://www. kuzbassanest.h15.ru/nutri.html

Хорошилов, И.Е. 2009. Клиническаянутрициология. СПб.:ЭЛБИ-СПб.284 с. ISBN 954-7-520-68569-3. 